\section{IAC 201CS and IAC 201CO: Crotalaria cultivars with high fresh matter yield and seed production}

\section{Sara Regina Silvestrin Rovaris ${ }^{1}$, Gabriel de Moraes Cunha Gonçalves ${ }^{1^{*}}$, Jean Fausto de Carvalho Paulino ${ }^{2}$, Simone Daneluz Gobbi $^{3}$, Alisson Fernando Chiorato ${ }^{1}$ and Sérgio Augusto Morais Carbonell ${ }^{1}$}

\begin{abstract}
The cultivars IAC 201CS and IAC 201CO have a mean cycle of 100 and 110 days, mean 1000 seed weight of 18 and 6 grams, mean total fresh matter weight of $26,287.81$ and $36,174.12 \mathrm{~kg} \mathrm{ha}^{-1}$, and mean seed weight of 812.57 and $1,017.09 \mathrm{~kg} \mathrm{ha}^{-1}$, respectively.
\end{abstract}

Keywords: Crotalaria spectabilis Roth, Crotalaria ochroleuca G., plant breeding, green manure.

\section{INTRODUCTION}

Crotalaria constitutes one of the largest genera of the Fabaceae family, with around 690 species distributed across tropical and subtropical regions, mainly in the southern hemisphere (Garcia et al. 2013). According to Pereira (2006), Crotalaria (rattlebox/rattlepod) rapidly grows to protect bare soil and provides large biomass production in a short period of time. As a green manure, it supplies a large amount of nitrogen to the soil, helps to control weed growth, and reduces the nematode population (Timossi et al. 2016).

Crotalaria ochroleuca $\mathrm{G}$. is an annual leguminous shrub with a determinate, upright growth habit. It adapts well to soil and climate conditions and, like Crotalaria juncea L., has an upright semi-woody stem. It has narrow leaves, an expressive proportion of stem in shoot biomass composition, and small seeds of reniform shape of various colors (Silva et al. 2016). It is susceptible to attack of the rattlebox moth Utetheisa ornatrix L. that, depending on intensity, can compromise seed production (Barreto and Fernandes 2001).

Crotalaria spectabilis Roth is a shrub plant of upright determinate growth habit, with a relatively early cycle, though initial development is slow, and it may reach a height of 1.0 to $1.5 \mathrm{~m}$ (Aguiar et al. 2014). It is used as a cover crop or green manure crop, like most Crotalarias, but also effectively acts as a trap plant in control of root-knot nematodes in infested soils (Leal et al. 2012, Aguiar et al. 2014). Under high temperature and moisture conditions, a fungal disease, septoria leaf spot/blotch (Septoria crotalariae), can arise in C. spectabilis, causing spots on leaves and early leaf drop, even leading to death of the plant (Maringoni et al. 2012). According to Araújo et al. (2015), mulch from C. spectabilis crop residue interferes in the population dynamics of coco-grass (Cyperus rotundus), with reduction in the population and in the dry biomass of that weed.
Crop Breeding and Applied Biotechnology 21(2): e36292129, 2021 Brazilian Society of Plant Breeding. Printed in Brazil http://dx.doi.org/10.1590/1984$70332021 v 21 n 2 c 38$
*Corresponding author: E-mail: gabriel_demoraes@hotmail.com (i) ORCID: 0000-0001-9745-0929

Received: 27 December 2021 Accepted: 08 March 2021 Published: 20 July 2021

${ }^{1}$ Instituto Agronômico de Campinas, Centro de Análises e Pesquisa Tecnológica do Agronegócio dos Grãos e Fibras, 13020-902, Campinas, SP, Brazil

${ }^{2}$ Instituto Agronômico de Campinas, Centro de Pesquisa e Desenvolvimento de Recursos Genéticos Vegetais, 13.020-902, Campinas, $\mathrm{SP}$, Brazil

${ }^{3}$ Empresa Mato-grossense de Pesquisa, Assistência e Extensão Rural, 78.550-258, Sinop, MT, Brazil 
As there is no supply of Crotalaria cultivars of the genera C. spectabilis and C. ochroleuca, the Instituto Agronômico (IAC) aimed to develop Crotalaria cultivars to meet market demand for new alternatives of leguminous plants for use as green manure. The cultivars IAC 201CO (C. ochroleuca) and IAC 201CS (C. spectabilis) show high potential for fresh matter and seed production.

\section{GENETIC ORIGIN AND DEVELOPMENT}

The Crotalaria ochroleuca cultivar IAC 201CO was developed by IAC. In November 2017, natural populations of Crotalaria ochroleuca belonging to the active germplasm bank (Banco Ativo de Germoplasma - BAG) of IAC were sown in Campinas, São Paulo. From these populations, 400 plants were selected, based on characteristics of fresh matter production (vigor) and the occurrence of rattlebox moth caterpillars Utetheisa ornatrix L. After evaluation of grain yield, 31 progenies from the plants selected in the previous year were sown in Campinas in November 2018. These 31 progenies were identified as Gen $\mathrm{CO} 1$ to Gen $\mathrm{CO} 31$. From them, eight superior lines of $C$. ochroleuca were selected. In April 2019, the 8 lines were sown in Campinas and Mococa, São Paulo, in a randomized block experimental design, with four replications, for preliminary evaluation and seed multiplication.

In October to December 2019, eight lines plus a check variety, corresponding to the traditional genotype sown by farmers, were sown in trials. The trials were conducted in six evaluation locations, three in the state of São Paulo: Campinas, Votuporanga, and Mococa, and three in the state of Mato Grosso: Canarana, Sinop, and Sorriso (on two dates) under a randomized block experimental design, with four replications. The area used for data collection was 4 $\mathrm{m}^{2}$ per plot. Due to its yield performance, the experimental line denominated Gen CO 23 was selected and given the commercial name IAC 201CO.

The Crotalaria spectabilis cultivar, IAC 201CS, was developed by IAC. In November 2017, natural populations of Crotalaria spectabilis belonging to the BAG of IAC were sown in Campinas, São Paulo. From these populations, 300 plants were selected based on the characteristics of fresh matter production (vigor) and the occurrence of disease (Septoria crotalariae). After evaluation of grain yield, 37 progenies from plants selected in the previous year were sown in Campinas in November 2018. These 37 progenies were identified as Gen CS 1 to Gen CS 37. From these progenies, 18 superior lines were selected. In April 2019, the 18 lines were sown in Campinas and Mococa, São Paulo, in a randomized block experimental design, with four replications, selecting nine superior lines.

In October, November, and December 2019, the nine lines of $C$. spectabilis plus a check cultivar, corresponding to the traditional genotype sown by farmers, were placed in trials for determination of plant technological qualities in six locations, three in the state of São Paulo: Campinas, Votuporanga, and Mococa, and three in the state of Mato Grosso: Canarana, Sinop, and Sorriso, in a randomized block experimental design, with four replications. The area used for data collection was $4 \mathrm{~m}^{2}$ per plot. Due to its yield performance, the experimental line denominated Gen CS 37 was selected and given the commercial name IAC 201CS.

\section{YIELD POTENTIAL}

The mean production values of total fresh matter weight (TFMW) considering all the environments in which the trials were conducted exhibited variation from $26,287.81$ to $22,645.11 \mathrm{~kg} \mathrm{ha}^{-1}$ for the $C$. spectabilis lines (Table 1). For C. ochroleuca (Table 2), the mean values of TFMW oscillated from 36,174.12 to 24,812.41 kg ha-1. The line Gen CS 37 had a high mean value of TFMW $\left(26,287.81 \mathrm{~kg} \mathrm{ha}^{-1}\right)$, which was significant, and it exceeded the production of the check variety by $16 \%$ (Table 1 ). The same situation was observed for the line Gen CO 23 , which exhibited a mean value of $36,174.12 \mathrm{~kg} \mathrm{ha}^{-1}$ for TFMW, statistically exceeding the check variety.

Regarding mean seed weight (SW), considering the mean values obtained in all the environments, the $C$. spectabilis lines ranged from 812.57 to $606.50 \mathrm{~kg} \mathrm{ha}^{-1}$. Once more, the Gen CS 37 line was highest, with a mean SW of $812.57 \mathrm{~kg} \mathrm{ha}^{-1}$, $29 \%$ higher than the check variety (Table 3). In relation to C. ochroleuca, the Gen CO 23 line exceeded seed production of the control variety by $13 \%$, with a SW of $1,017.09 \mathrm{~kg} \mathrm{ha}^{-1}$ (Table 4).

Due to their higher mean values for TFMW and for SW, the Instituto Agronômico (IAC) selected the Gen CS 37 line of C. spectabilis and named it IAC 201CS, and the Gen CO 23 line of C. ochroleuca and named it IAC 201CO. The name of the 
cultivars regarding the IAC abbreviation corresponds to the Instituto Agronômico de Campinas; 20 is related to the year of registration in the Brazilian Ministry of Agriculture's National Cultivar Registry (MAPA/RNC); 1 is the number of registry of both Crotalaria species by IAC; and CS and CO correspond to the $C$. spectabilis and C. ochroleuca species, respectively.

The cultivars IAC 201CS and IAC 201CO were registered in the National Cultivar Registry (Registro Nacional de Cultivares - RNC) of the Brazilian Ministry of Agriculture (Ministério da Agricultura, Pecuária e Abastecimento - MAPA) on November 17, 2020, under number 46304 and 46303, respectively.

\section{OTHER CHARACTERISTICS}

The IAC 201CS cultivar has an annual cycle, with flowering at an average of 70 days and maturation at an average of 100 days after emergence. Mean plant height was from 1.0 to 1.5 meters, and mean 1000 seed weight was $18 \mathrm{~g}$. A

Table 1. Mean total fresh matter weight (TFMW) in $\mathrm{kg} \mathrm{ha}^{-1}$, coefficient of variation (CV\%), and least significant difference (LSD, Dunnett $-p<0.05$ ) of genotypes of Crotalaria spectabilis Roth considering six evaluation locations, as well as the combination of environments, 2019/20 crop year

\begin{tabular}{|c|c|c|c|c|c|c|c|}
\hline \multirow{3}{*}{ Genotype of Crotalaria spectabilis } & \multicolumn{6}{|c|}{ TFMW (kg ha-1) } & \multirow{3}{*}{$\begin{array}{c}\text { Combined } \\
\text { Analysis }\end{array}$} \\
\hline & \multicolumn{6}{|c|}{ Analysis by location } & \\
\hline & Campinas & Mococa & Votuporanga & Sorriso & Sinop & Canarana & \\
\hline Gen CS 37 & $45,093.75$ & $19,061.88$ & $38,381.25$ & $32,656.25$ & $12,727.50$ & $9,806.25$ & $26,287.81^{*}$ \\
\hline Gen CS 3 & $42,987.50$ & $15,317.50$ & $38,281.25$ & $29,812.50$ & $15,088.75$ & $11,384.38$ & $25,478.64^{*}$ \\
\hline Gen CS 27 & $44,456.25$ & $16,110.63$ & $32,618.75$ & $30,250.00$ & $12,265.63$ & $12,378.13$ & $24,679.89$ \\
\hline Gen CS 4 & $40,343.75$ & $15,091.88$ & $34,250.00$ & $29,593.75$ & $15,538.75$ & $12,565.63$ & $24,563.95$ \\
\hline Gen CS 26 & $38,418.75$ & $15,273.75$ & $33,687.50$ & $29,312.50$ & $12,711.88$ & $9,715.63$ & $23,186.66$ \\
\hline Gen CS 17 & $35,337.50$ & $14,423.75$ & $35,268.75$ & $29,056.25$ & $13,359.38$ & $11,603.13$ & $23,174.79$ \\
\hline Gen CS 32 & $41,025.00$ & $12,002.50$ & $31,662.50$ & $28,812.50$ & $8,755.00$ & $13,228.13$ & $22,580.93$ \\
\hline Check Variety & $34,356.25$ & $15,935.00$ & $34,737.50$ & $29,093.75$ & $9,607.50$ & $12,140.63$ & $22,645.11$ \\
\hline Overall Mean & $40,208.75$ & $15,380.68$ & $34,981.25$ & $29,699.37$ & $12,518.00$ & $11,922.50$ & $24,118.43$ \\
\hline
\end{tabular}

* Dunnett test $(p<0.05)$.

Table 2. Mean total fresh matter weight (TFMW) in $\mathrm{kg} \mathrm{ha}^{-1}$, coefficient of variation (CV\%), and least significant difference (LSD, Dunnett $-p<0.05$ ) of genotypes of Crotalaria ochroleuca $\mathrm{G}$. considering six evaluation locations, as well as the combination of environments, 2019/20 crop year

\begin{tabular}{|c|c|c|c|c|c|c|c|}
\hline \multirow[b]{3}{*}{ Genotype of Crotalaria ochroleuca } & \multicolumn{6}{|c|}{ TFMW $\left(\mathrm{kg} \mathrm{ha}^{-1}\right)$} & \multirow{3}{*}{$\begin{array}{c}\text { Combined } \\
\text { Analysis }\end{array}$} \\
\hline & \multicolumn{6}{|c|}{ Analysis by location } & \\
\hline & Campinas & Votuporanga & $\begin{array}{c}\text { Sorriso } \\
\text { (Nov/2019) }\end{array}$ & Sorriso (Dec/2019) & Sinop & Canarana & \\
\hline Gen CO 29 & 93.127 .37 & 37.015 .00 & 25.967 .50 & 24.804 .37 & 6.499 .37 & 12.781 .87 & 33.365 .91 \\
\hline Gen CO 2 & 63.786 .37 & 26.288 .12 & 21.690 .62 & 21.094 .37 & 4.351 .25 & 11.663 .75 & 24.812 .41 \\
\hline Gen CO 18 & 99.320 .62 & 23.581 .87 & 19.247 .50 & 23.213 .75 & 8.141 .87 & 13.943 .75 & 31.241 .56 \\
\hline Gen CO 15 & 79.623 .75 & 31.054 .37 & 22.139 .37 & 22.620 .00 & 4.994 .37 & 14.900 .00 & 29.221 .98 \\
\hline Gen CO 12 & 84.010 .75 & 27.865 .00 & 24.172 .50 & 24.753 .75 & 5.968 .75 & 13.903 .75 & 30.112 .42 \\
\hline Check variety & 79.289 .50 & 40.262 .37 & 23.001 .25 & 22.176 .87 & 8.313 .75 & 13.603 .25 & 31.107 .83 \\
\hline Overall mean & 86.915 .64 & 33.577 .85 & 23.002 .08 & 23.335 .48 & 6.421 .32 & 13.131 .61 & 30.999 .80 \\
\hline
\end{tabular}

* Dunnett test $(\mathrm{p}<0.05)$. 
Table 3. Mean seed weight (SW) in $\mathrm{kg} \mathrm{ha}^{-1}$, coefficient of variation (CV\%), and least significant difference (LSD, Dunnett - $\left.p<0.05\right)$ of genotypes of Crotalaria spectabilis Roth considering six evaluation locations, as well as the combination of environments, $2019 / 20$ crop year

\begin{tabular}{|c|c|c|c|c|c|c|c|}
\hline \multirow{3}{*}{ Genotype of Crotalaria spectabilis } & \multicolumn{6}{|c|}{ SW $\left(\mathrm{kg} \mathrm{ha}^{-1}\right)$} & \multirow{3}{*}{$\begin{array}{c}\text { Combinec } \\
\text { Analysis }\end{array}$} \\
\hline & \multicolumn{6}{|c|}{ Analysis by location } & \\
\hline & Campinas & Mococa & Votuporanga & Sorriso & Sinop & Canarana & \\
\hline Gen CS 4 & 306.73 & 1.776 .12 & 1.208 .66 & 663.49 & 61.89 & 721.50 & $789.73^{*}$ \\
\hline Gen CS 37 & 404.82 & 966.50 & 1.513 .61 & 629.21 & 55.89 & $1,305.37$ & $812.57^{*}$ \\
\hline Gen CS 28 & 314.48 & 1.220 .63 & 1.473 .39 & 664.08 & 91.27 & 760.31 & $754.02 *$ \\
\hline Gen CS 17 & 360.71 & 1.158 .13 & 1.325 .82 & 453.13 & 86.26 & 850.00 & 705.67 \\
\hline Gen CS 3 & 313.69 & 1.825 .00 & 946.86 & 475.09 & 41.79 & 652.37 & 709.13 \\
\hline Gen CS 21 & 337.18 & 976.88 & 1.412 .72 & 366.44 & 60.49 & 485.31 & 606.50 \\
\hline Gen CS 26 & 312.93 & 1.408 .13 & 1.152 .68 & 346.99 & 35.57 & 395.62 & 608.65 \\
\hline Check variety & 289.47 & 1.367 .37 & 1.199 .26 & 346.72 & 72.67 & 485.47 & 626.82 \\
\hline Overall mean & 330.31 & 1.286 .00 & 1.363 .96 & 495.12 & 64.39 & 661.88 & 700.87 \\
\hline
\end{tabular}

* Dunnett test $(\mathrm{p}<0.05)$.

Table 4. Mean seed weight (SW) in $\mathrm{kg} \mathrm{ha}^{-1}$, coefficient of variation (CV\%), and least significant difference (LSD, Dunnett - p<0.05) of genotypes of Crotalaria ochroleuca G. considering seven evaluation locations, as well as the combination of environments, $2019 / 20$ crop year

\begin{tabular}{|c|c|c|c|c|c|c|c|c|}
\hline \multirow[b]{3}{*}{ Genotype of Crotalaria ochroleuca } & \multicolumn{7}{|c|}{ SW $\left(\right.$ kg ha $\left.^{-1}\right)$} & \multirow{3}{*}{$\begin{array}{l}\text { Combined } \\
\text { Analysis }\end{array}$} \\
\hline & \multicolumn{7}{|c|}{ Analysis by location } & \\
\hline & Campinas & Mococa & Votuporanga & $\begin{array}{c}\text { Sorriso } \\
\text { (Nov/2019) }\end{array}$ & Sorriso (Dec/2019) & Sinop & Canarana & \\
\hline Gen CO 29 & 199.52 & 494.25 & 2.504 .37 & 1.875 .53 & 1.550 .58 & 219.43 & 158.91 & $1.000 .37^{*}$ \\
\hline Gen CO 2 & 221.48 & 346.41 & 2.432 .50 & 2.303 .18 & 1.662 .38 & 269.39 & 168.28 & $1.057 .66^{*}$ \\
\hline Gen CO 18 & 175.00 & 376.74 & 2.154 .37 & 2.651 .39 & 1.387 .69 & 266.73 & 157.91 & $1.024 .26^{*}$ \\
\hline Gen CO 15 & 206.83 & 428.36 & 2.060 .00 & 1.267 .65 & 1.675 .54 & 180.39 & 157.97 & 853.82 \\
\hline Gen CO 12 & 187.37 & 363.36 & 1.677 .50 & 1.832 .91 & 1.599 .97 & 297.24 & 156.57 & 873.56 \\
\hline Check variety & 237.54 & 220.46 & 1.225 .83 & 2.606 .78 & 1.634 .10 & 157.70 & 172.37 & 893.54 \\
\hline Overall mean & 192.49 & 360.55 & 2.095 .04 & 2.063 .23 & 1.530 .45 & 240.83 & 161.10 & 949.10 \\
\hline
\end{tabular}

* Dunnett test $(\mathrm{p}<0.05)$.

between-row spacing of $50 \mathrm{~cm}$ and 15-18 plants per linear meter is recommended, resulting in a mean population of 300.000 to 360.000 plants per hectare.

The IAC 201CO cultivar has an annual cycle with flowering at an average of 82 days and maturation at an average of 110 days after emergence. Mean plant height was from 1.5 to 2.0 meters and mean 1000 seed weight was 6 grams. A between-row spacing of $50 \mathrm{~cm}$ and 15-18 plants per linear meter is recommended, resulting in a mean population of 300.000 to 360.000 plants per hectare.

\section{TECHNICAL RECOMMENDATIONS AND SEED PRODUCTION}

Sowing of the IAC 201CS e IAC 201CO cultivars is recommended in October/November for the South/Southeast region in the states of SC, RS, PR, SP, and MG, and for the Central West region in the states of MT, MS, GO, TO, and DF. 
IAC 201CS and IAC 201CO: Crotalaria cultivars with high fresh matter yield and seed production

\section{REFERENCES}

Aguiar TEA, Gonçalves C, Paterniani MEAGZ, Tucci MLS and Castro CEF (2014) Instruções agrícolas para as principais culturas econômicas. Instituto Agronômico, Campinas, 452p. (Boletim IAC, nr. 200)

Araújo LS, Cunha PCR, Silveira PM, Sousa Netto M and Oliveira FC (2015) Potencial de cobertura do solo e supressão de tiririca (Cyperus rotundus) por resíduos culturais de plantas de cobertura. Revista Ceres 62: 483-488.

Barreto AC and Fernandes MFF (2001) Recomendações técnicas para o uso da adubação verde em solos de tabuleiros costeiros. Embrapa Tabuleiros Costeiros, Aracaju, 7p. (Circular técnica, 19).

Garcia JM, Kawakita K, Miotto STS and Souza MC (2013) O gênero Crotalaria L. (Leguminosae, Faboideae, Crotalarieae) na planície de inundação do Alto Rio Paraná, Brasil. Revista Brasileira de Biociências 11: 209-226.
Leal MAA, Guerra JGM, Peixoto RTG and Almeida DL (2012) Desempenho de crotalária cultivada em diferentes épocas de semeadura e de corte. Revista Ceres 59: 386-391.

Maringoni AC, Veronese M and Crusciol CAC (2012) Ocorrência de septoriose em Crotalaria spectabilils no Estado de Mato Grosso, Brasil. Summa Phytopathology 4: 344.

Pereira AR (2006) Como selecionar plantas para áreas degradadas e controle de erosão. FAPI, Belo Horizonte, 239p.

Silva AG, Azeredo GA, Souza VC, Marini FS and Pereira EM (2016) Influência da cor do tegumento e da temperatura na germinação e vigor de sementes de Crotalaria ochroleuca L. Revista Verde de Agroecologia e Desenvolvimento Sustentável 11: 49-54.

Timossi PC, Silva Junior HR, Lima SF, Castro R and Almeida DP (2016) Adubação antecipada com fertilizantes orgânico e mineral associado à crotalarias na cultura do milho. Revista Brasileira de Milho e Sorgo 3: 500-509. 